\title{
Study on the Valuation of Livestock Production in the Typical Farming-Pastoral Area on the Tibetan Plateau
}

\author{
Weiwei Yang \\ School of Economics and Management \\ Beijing University of Technology \\ Beijing, PRC \\ janeyang99@hotmail.com
}

\author{
Zhandui Luorong \\ Institute of Sociology and Economics \\ Chinese Center of Tibetology \\ Beijing, PRC \\ luorzhd@126.com
}

\begin{abstract}
The authors selected a typical farming-pastoral village. They interviewed herders and farmers who engage in range-based animal husbandry to gain an understanding and formulate an analysis of the market and non-market value of livestock products, and evaluated the contribution of the livestock products to local economic development and the improvement of people's livelihood.
\end{abstract}

\section{Keywords-livestock product; market value; non-market value}

\section{REPRESENTATIVE INTRODUCTION OF CHUNDUI VILLAGE}

We selected the Chundui village in Lhunzhub county as the field site, which is located in the 100 kilometers north of downtown Lhasa City. With an elevation of $3850 \mathrm{~m}$, it belongs to semi-arid climatic type. According to the statistical data compiled at different levels of government in the region, the number of domestic animals in the village was 3513 heads, including yak, ox, sheep, goat, pig, horse and donkey. Most of these domestic animals were raised by Tibetans in higher elevated regions of the Tibetan Autonomous Region. The region belongs to agricultural and pastoral areas in river valleys in the southern Tibet Autonomous Region, whose production system is sedentary or pastoralist. It has the representative features fitting the purpose of this study.

By the end of 2009, there were 102 households with 636 people in Chundui village. Its plough area was $2284 \mathrm{ke} 1$. There were 3513 heads (pieces) livestock, 6365 sheep units. Among them, 2800 sheep, 300 cows, 180 cattle, 130 yaks, 96 donkeys, 7 horses, 160 pigs and 11 chicken.

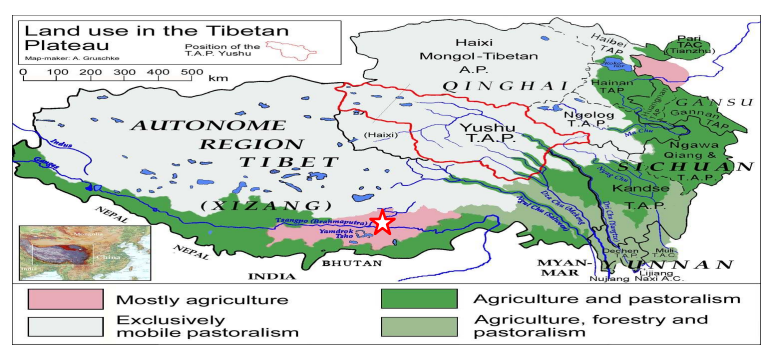

FIGURE 1.

\section{BACKGROUND INFORMATION OF RESPONDENTS}

To support the development of animal husbandry, Chinese government promulgated "The Animal Husbandry Act of the People's Republic of China" in 2006. And in order to speed up the development of animal husbandry, Tibetan government provided some of the following technical support during the 11th Five-Year:

- The technology of efficient yak breeding. The profit of yak breeding improved by $15 \% \sim 20 \%$ compared with that of the 10th Five-Year.

- The technology of cattle improvement and efficient breeding.

- Animal epidemic sources and disease monitoring and early warning system

- The technology of sheep efficient breeding.

- Yak breeding and variety selection

- Cultivation of new species of highland barley

We selected 20 people from 20 households as our respondents. The 7 females and 13 males were all Tibetans, at the average age of 48 years old, with 37 as the youngest, and 65 the oldest. They all selected sedentary or pastoralist production type. (See Figure.2)

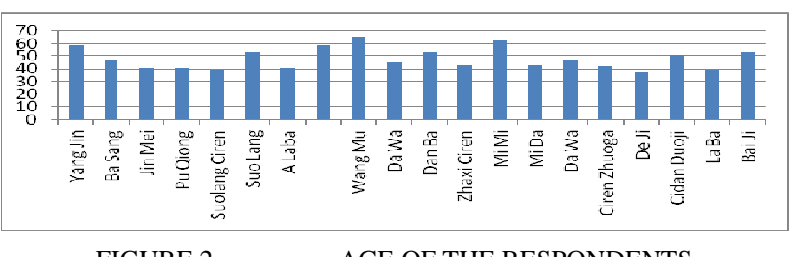

FIGURE 2 .

AGE OF THE RESPONDENTS

Regarding the ratio of adult males within these 20 households, the minimum is 1 adult male / household, the maximum is 7 , and the average is 3.3 ; for adult females, the minimum is 1 adult female / household, the maximum is 5 , and the average is 3.0 ; for male child, the minimum is 0 male child / household, the maximum is 2 , and the average is 0.6 ; for female child, the minimum is 0 female child / household, the maximum is 3 , the average is 1.1. All the respondents were married. (See Figure.3) 


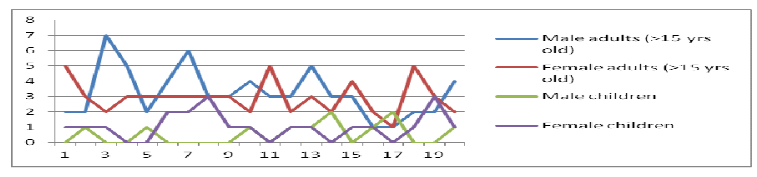

FIGURE 3.

HOUSEHOLD MEMBER COMPOSITION

About the number of household numbers working outside their living town, 4 households have neither male or female outside workers; 2 households have both male and female outside workers; for the other 14 households, 11 have only male outside workers, and 3 have female outside workers. So for the ratio of male outside workers within these 20 households, the minimum is 0 , the maximum is 4 , and the average is 1.2 ; for female outside workers, the minimum is 0 , the maximum is 1 , and the average is 0.3 . (See Figure.4)

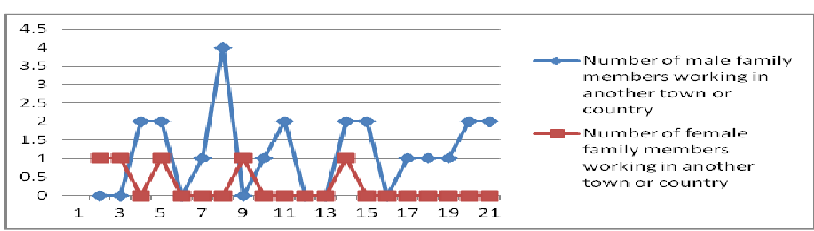

FIGURE 4. GENDER CALCULATION OF HOUSEHOLD NUMBERS WORKING OUTSIDE THEIR LIVING TOWN

In the aspect of pastoralist within these 20 households, 16 households' pastoralists are merely male, the maximum is 2 male pastoralist / household, and the average is 0.9. 4 households' pastoralists are merely female (one pastoralist for one household), and the average is 0.2 male pastoralist / household. (See Figure.5)

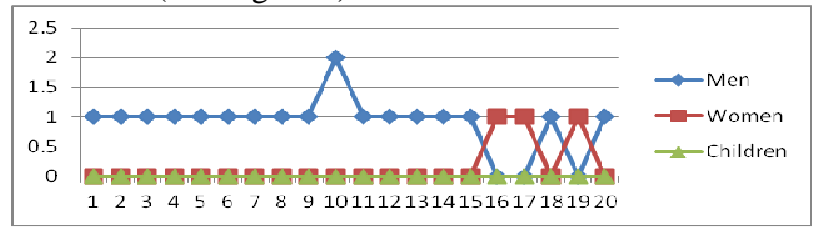

FIGURE 5

\section{NUMBER OF FAMILY MEMBERS INVOLVED} IN HERDING LIVESTOCK

There are no children pastoralists among all the respondents; all their livestock grazed in community pasture; none of the respondents own rangeland with exclusive grazing rights or forest with wood and fuel.

So far, the species and value calculation of mature livestock ( $>1$ year old) in respondents' households are listed as follows:

TABLE I. THE SPECIES AND VALUE CALCULATION OF MATURE LIVESTOCK ( $>1$ YEAR OLD) IN RESPONDENTS' HOUSEHOLDS

\begin{tabular}{|c|c|c|c|c|c|}
\hline & $\begin{array}{c}\text { Minimum } \\
\text { amount }\end{array}$ & $\begin{array}{c}\text { Maximum } \\
\text { amount }\end{array}$ & $\begin{array}{c}\text { Household } \\
\text { average } \\
\text { amount }\end{array}$ & $\begin{array}{c}\text { Total } \\
\text { value } \\
(\$)\end{array}$ & $\begin{array}{c}\text { Average } \\
\text { value } \\
(\$)\end{array}$ \\
\hline Cattle & 2 & 16 & 7.2 & 7169.23 & 358.5 \\
\hline Yaks & 0 & 40 & 3.9 & 1769.23 & 88.5 \\
\hline Buffalos & 0 & 0 & 0 & 0 & 0 \\
\hline Camels & 0 & 0 & 0 & 0 & 0 \\
\hline Horses & 0 & 3 & 0.3 & 1230.77 & 61.5 \\
\hline Mules & 0 & 0 & 0 & 0 & 0 \\
\hline
\end{tabular}

\begin{tabular}{|c|c|c|c|c|c|}
\hline Donkeys & 0 & 2 & 0.8 & 738.46 & 36.92 \\
\hline Sheep & 0 & 87 & 16.4 & 470 & 23.5 \\
\hline Goats & 0 & 45 & 10.2 & 364 & 18.2 \\
\hline Pigs & 0 & 4 & 1.0 & 1470 & 73.5 \\
\hline Rabbits & 0 & 0 & 0 & 0 & 0 \\
\hline Chicken & 0 & 3 & 0.2 & 4 & 0.2 \\
\hline
\end{tabular}

Explanation: among the 20 respondent households, merely 4 households own yaks, 3 households have horses, and 1 household raises 3 chickens. The respondents answered 43 questions about raising livestock, and the answers are summarized as follows:

- 21 answers: " Due to intensifying drought these years, straw production has become scarce, which leads to shortage of dry feed in spring and winter" and "Straw and other feeds are scarce" , 48.84\%

- 8 answers: " no more natural grass to feed animal" , $18.6 \%$;

- 5 answers: " Lacking labor force to raise animal in pasture", $11.63 \%$;

- 5 answers: "Cash is scarce" , 11.63\%;

- 4 answers: " the price of fodder is going up" , $9.3 \%$

As for the question of "What were the main problems you faced 10 years ago with keeping livestock" , the respondents gave 22 answers. Except the 3 answers of "None" and 1 answer of "we had not livestock /no idea" , the other 18 answers are concluded as follows:

- 11answers: "Straw and other feeds were also scarce” , 61.11\%;

- 3 answers: “Due to relative Poverty” ,16.67\%;

- 3 answers: “Labor force was not enough" , $16.67 \%$;

- 1 answer: "Because of the scarcity of grass for livestock”, 5.56\%。

\section{MARKET VALUES}

According to the questionnaire, in the three aspects of "Sales of livestock belonging to household during last 12 months and income from sales", "Milk and livestock products sold during the last 12 months", and "Sales of value-added products made from animal fibres and skins/hides during last 12 months", the 20 households' gross annual income is $\$ 14828.74$, and the average is $\$ 741.44$.

Among these 20 households, the highest income of selling adult cattle was $\$ 1538.46$, the least was $\$ 0$ (11 households); merely one household had income from selling adult sheep, which brought them $\$ 549.23$; only one household gained from selling adult goat, earning \$200; only one household earned from selling young cattle with $\$ 23.08$ income. The highest income of selling milk and other livestock products is $\$ 1856.89$, the least is $\$ 0$ (6 households); 3 households sold cheese, and each gained 
$\$ 169.23$, \$45.54 and \$16.15 respectively; 4 households sold meat, and each earned $\$ 1800, \$ 1292.31, \$ 1153.85$ and $\$ 738.46$ respectively; 5 households sold cashmere, and the highest income is $\$ 161.54$; one household sold goat hair with $\$ 59.08$; skins were sold by 13 households, and the highest income is $\$ 96$. Only one household sold manure and gain \$61.54; the highest income of gross annual income from "value-added products made from animal fibres and skins/hides during last 12 month" is $\$ 384.62$, and the least is $\$ 0$ (7 households); therein, 13 households earned from packing animals, and the highest one gained $\$ 230.77 ; 3$ households earned from drafting animals, and each of them gained \$153.85. (See Figure.6 and Figure. 7)

Among these 20 households, the total revenue of wheat is $\$ 47.54$, and the average is $\$ 2.38$. The total revenue of potatoes is $\$ 370.15$, and the average is $\$ 18.51$. They spent $\$ 1523.08$ on purchases of rice, and $\$ 328$ on purchases of highland barley.

\section{Explanation:}

The questions in questionnaire cannot completely reflect the market exchange values of Tibetan people, because it is not unusual for people to use traditional market exchange system (barter system) in this area. For instance: in order to get ghee, famers in agricultural areas would like to entrust their yaks to pastoralists' households in pasturing areas. The exchange system is very complicated:

- All yoghourt is owned by pastoralists;

- All yak hair belongs to pastoralists.

- If a mother yak bears a young bull, the bull will belong to pastoralists; if a mother yak bears a young cow, the cow will belong to famers.

- In summer, famers are allowed to collect 2 tractors of dung.

- Farmers are expected to bring some clothes and drinks to pastoralists when collecting dung in pasturing areas.

- In winter, 1 tractor of straw should be given to pastoralists, etc.

The traditional exchange system accounts for a large part of exchange system in the livelihood of Tibetan, however, it is difficult to reflect this part accurately in the questionnaire. In the traditional exchange system, highland barley serves as the general equivalent of the market. When they have enough cash, pastoralists and peasants exchange commodities with cash. When they have not enough cash, they usually exchange many commodities with highland barley. Highland barley is an important resource for the livelihood of many residents in the region, particularly the Tibetans. Highland barley as the general equivalent of all other commodities is the convention of local society and has been established through history.

(Note: Highland barley production is the main raw material for Tibetan people to make Zanba, and it can be grounded to make barley fried noodle with butter.)

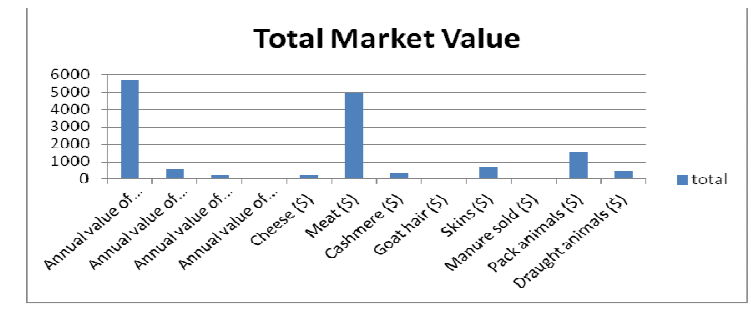

\section{FIGURE 6. TOTAL MARKET VALUE OF SELLING LIVESTOCK PRODUCTS}

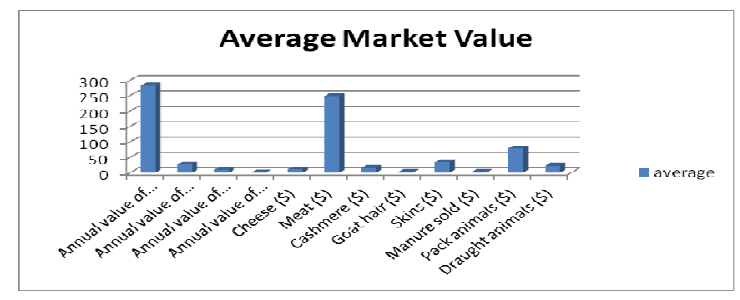

FIGURE 7. AVERAGE MARKET VALUE OF SELLING LIVESTOCK PRODUCTS

\section{NON-MARKET VALUES}

The total value of their own livestock used for guests, weddings etc for these 20 respondent households in the last 12 months was $\$ 5338.46$, with an average of $\$ 266.92$ per household. Sheep was the most frequently used livestock. It was used by 11 households whose highest expense in these aspects was \$192.31. By contrast, goat was the least frequently used livestock with average household expenses of $\$ 153.85$ for guests, weddings etc. 2 households used yak, and spent $\$ 692.31$ and $\$ 738.46$ respectively; pig was used by 2 households with the expenses of $\$ 138.46$ and $\$ 107.69$ respectively. 6 households used cattle, and the highest expense was $\$ 923.08$. From the perspective of value, cattle is the most widely consumed at the value of $\$ 2630.77$; the second is yak which valued $\$ 1430.77$; followed by sheep, $\$ 876.92$, pig, $\$ 246.15$; the last is goat which valued $\$ 153.85$. (See Figure.8 and Figure. 9)

From the herding of livestock, peasants can get the most important sources of nutrition for themselves and for their land - milk products and dung. The most important material for heating/energy is dung, while the most important materials for protecting themselves against cold are animal hair and skin. The complementation of farming and herding is considered to be the foundation and basic principle of traditional economy in Tibetan communities.

The higher non-market value is caused by following reasons:

- There are 2 important festivals in Tibet, which accounted for $20 \%$ of total consumption value on self-owned livestock.

- Tibetans hold religious ceremonies about 2-3 times per year, and every village has a collective religion ceremony each year. $25 \%$ of total consumption 
value on self-owned livestock are spent in this aspect.

- Since the implementation of government housing project last year, Tibetan households need to provide food to other villagers who come to help the construction, which amounts to $45 \%$ of total consumption value on self-owned livestock.

- $5 \%$ of total consumption value on self-owned livestock is spent on weddings and funerals.

- Celebration for children going to school costs 5\% of total consumption value on self-owned livestock.

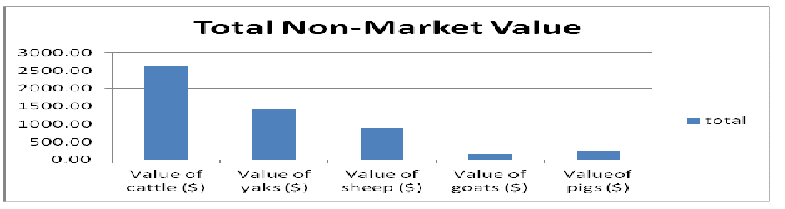

FIGURE 8. TOTAL NON-MARKET VALUE OF CONSUMING SELF-OWNED LIVESTOCK PRODUCTS

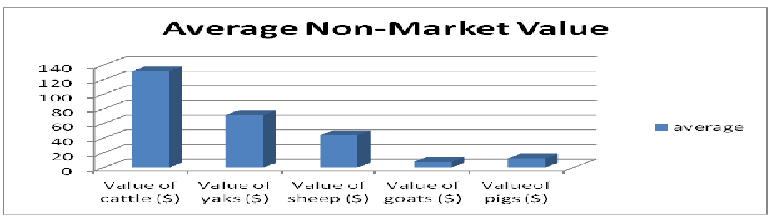

\section{FIGURE 9. AVERAGE NON-MARKET VALUE OF} CONSUMING SELF-OWNED LIVESTOCK PRODUCTS

\section{OTHERS}

"Likeliness to invest in additional livestock in future". 15 households' pastoralists want to invest in good cow, because dairy cows can yield more milk, produce more butter and selling dairy calves can earn more money. 5 households' pastoralists want to invest in little bull, because little bull can be raised in captivity, and it produces more meat. If it is strong, it can be used to breed. 4 households' pastoralists choose yak, because yak can make more money. 2 households' pastoralists choose pig, because the price of pig, especially the price of local Tibetan pig, has been going up sharply. 1 household' pastoralist hopes to invest in sheep, because selling sheep can earn more money. (See Figure.10)

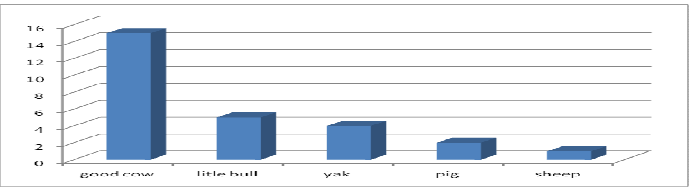

FIGURE 10.

LIKELINESS TO INVEST IN ADDITIONAL LIVESTOCK IN FUTURE

"If you wish to invest in more livestock, where feed would come from?" 17 households' pastoralists choose to produce more Japan peas, alfalfa, wheat, barley straw, etc. 12 households' pastoralists choose to buy feed from market, other villages or households do not plan to buy more livestock. 8 households' pastoralists choose to ask nomad relatives or friends to raise livestock in pasture areas. 2 households' pastoralists choose to get the feed from grassland nearby. (See Figure.11)

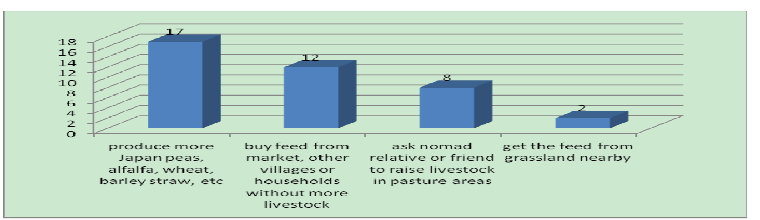

FIGURE 11

\section{SOURCES OF FEED}

"Production of milk, wool, cashmere, etc during the last 12 months"

According to the questionnaire, the total animal milk production of these 20 households is $17216 \mathrm{~kg}$, and the average is $860.8 \mathrm{~kg}$.

In the "production of milk products and animal fibres", the "Total production of Yoghurt" is $1082 \mathrm{~kg}$, and the average is $54.1 \mathrm{~kg}$, and totally used in house for consumption and processing. The "Total production of Cheese" is $605 \mathrm{~kg}$, and the average is $30.23 \mathrm{~kg}$, and totally used in house for consumption and processing. The "Total production of Ghee" is $829 \mathrm{~kg}$, and the average is $41.45 \mathrm{~kg}$, and totally used in house for consumption and processing. The "Total production of Wool" is $182 \mathrm{~kg}$, and the average is $9.12 \mathrm{~kg}$, and totally used in house for consumption and processing. The "Total production of Cashmere" is $22 \mathrm{~kg}$, and the average is $1.11 \mathrm{~kg}$. (See Figure.12)

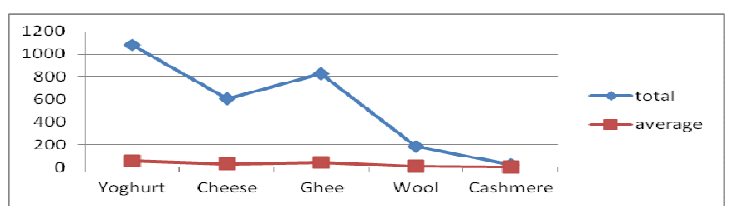

\section{FIGURE 12. TOTAL AND AVERAGE PRODUCTION OF} MILK PRODUCTS AND ANIMAL FIBRES

In the "Production of animal fibres and manure", the "Total production of Goat hair" is $57 \mathrm{~kg}$, and the average is $2.85 \mathrm{~kg}$. The "Total production of Yak hair" is $35 \mathrm{~kg}$, and the average is $1.77 \mathrm{~kg}$. The "Total production of Skins" is 103 pieces, and the average is 1.15 pieces. The "Total production of Other Manure as firewood" is $36200 \mathrm{~kg}$, and the average is $1810 \mathrm{~kg}$. The "Total production of Manure" is $33200 \mathrm{~kg}$, and the average is $1660 \mathrm{~kg}$. (See Figure.13)

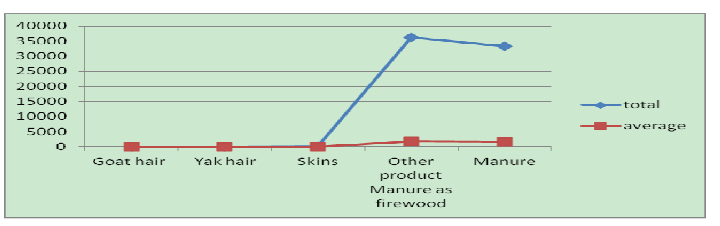

FIGURE 13.

TOTAL AND AVERAGE PRODUCTION OF ANIMAL FIBRES AND MANURE

In the "Quantity of edible and non-edible livestock products used in house for consumption and processing during the last 12 months", the "Quantity of Milk used in house for consumption and processing" is 845 litre, and the 
average is 42.23 litre. The "Quantity of Meat used in house for consumption and processing" is $4436 \mathrm{~kg}$, and the average is $221.8 \mathrm{~kg}$. The "Quantity of Wool used in house for consumption and processing" is $232 \mathrm{~kg}$, and the average is $11.62 \mathrm{~kg}$. The "Quantity of Cashmere used in house for consumption and processing" is $7 \mathrm{~kg}$, and the average is $0.3575 \mathrm{~kg}$. The "Quantity of Goat hair used in house for consumption and processing" is $43.05 \mathrm{~kg}$, and the average is $2.1525 \mathrm{~kg}$. The "Quantity of Yak hair used in house for consumption and processing" is $43.4 \mathrm{~kg}$, and the average is $2.17 \mathrm{~kg}$. The "Quantity of Skins used in house for consumption and processing" is 4pieces, and the average is 0.2 pieces. (See Figure.14)

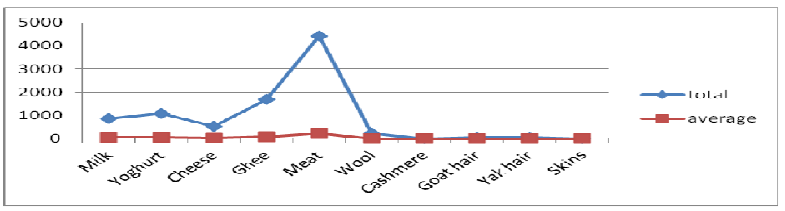

FIGURE. 14 TOTAL AND AVERAGE QUANTITY OF EDIBLE AND NON-EDIBLE LIVESTOCK PRODUCTS USED IN HOUSE FOR CONSUMPTION AND PROCESSING DURING THE LAST 12 MONTHS

"Ownership of land and assets"

The average size of irrigated cropland of per household is 1.9445 ha. The average size of rainfed cropland of per household is 0.066 ha. There are .01 motor vehicles, 1.35 tractors, 1.3 motorcycles, 1.3 televisions, 1.75 telephones, 0.5 refrigerators, 0.35 cream separators, 0.15 solar panels, 1 room for looms, 0.55 tents, 1 house per household. (See Figure.15)

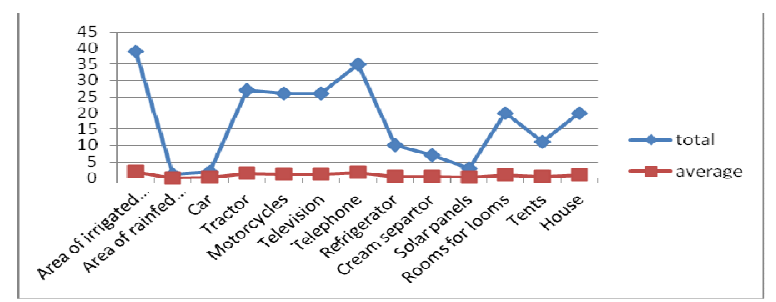

FIGURE. 15 TOTAL AND AVERAGE OWNING OF LAND AND ASSETS

\section{CONCLUSIONS}

From this questionnaire research and analysis, we can draw conclusions as follows:

- The market value of livestock production accounts for $20.07 \%$ of total income (total income $=$ market value of livestock production - non-market value of livestock production + other income + income of agricultural production)

- The non-market value of livestock production accounts for $7.22 \%$ of total income

- Although the questionnaire included some questions regarding women's participation, the results did not meet the goal of investing into women's involvement .

\section{Two explanations:}

- In terms of calculating livestock production values, the questionnaire can only reflect limited part of Tibetans' dairy life. This is due to the fact that different from the current market exchange system, there still exist many situations of traditional market exchange system, which are not included in this research scope. However, this part is a crucial reflection of real life in Tibet and it is necessary to carry out some further analysis.

- Most of the HKH area is in China. The Tibetan Plateau is vast in territory, with an area of 2.5 million sq.km (0.97 million sq. mi., or about four times the size of France1). Total HKH regional area is approximately $3,441,719$ sq.km.2 It is the origin of many rivers in Asia, having a major ecological and environmental impact on a wide variety of areas downstream. Nearly two million hectares of grassland occupy more than half of the plateau, playing an important role in water conservation, environmental protection and maintaining the biodiversity of the plateau. Moreover, the natural grassland is also an important resource for the livelihood of many residents in the region, particularly the Tibetans. The study of livestock production on the Tibetan Plateau attaches great significance to ecological security, livelihood improvement, and the coordination of regional development on the plateau and in the HKH region. A deep and detailed research is needed if we would like to have a comprehensive understanding of this area.

\section{ACKNOWLEDGMENT}

Financial support for this study was provided by the International Center for Integrated Mountain Development(ICIMOD).

11 "Ke" is equal to $14 \mathrm{~kg}$ of highland barley or wheat; 1 "Ke" is equal to $12 \mathrm{~kg}$ rapes; 1 "Ke" is equal to $15 \mathrm{~kg}$ peas.

\section{REFERENCES}

[1] Stephen Hynes and Brian Cahill. "Valuing the benefits to the local community of supplying recreational facilities in community owned forests: an application of the contingent behaviour method". Small scale Forestry. 2007(3), pp.219-231.

[2] David Dole. "Implicit Valuation of Non-Market Benefits in EvenAged Forest Management". Environmental and Resource Economics. 02/1999(1) pp.95-105.

[3] JIN Jian-jun, WANG Yu-hai, LIU Xue-min. "Analysis on the NonMarket Value of Cultivated Land Resources and Its Valuation Methods". Ecological Economy(in Chinese). 2008(1), pp. 39-41.

[4] ZHAO Xueyan. "Review of the ecological compensation efficiency". Ecologica Sinica. 2012(3) pp.1960-1969.

\footnotetext{
${ }^{1}$ http://en.wikipedia.org/wiki/Tibetan_Plateau

http://www.icimod.org/?q=1137
} 